\title{
Teologia Espiritual da Libertação Indicações preliminares para a continuidade da Teologia da Libertação
}

Celso Pinto Carias

\section{Introdução}

A teologia da libertação (t.d.1.) está morta e enterrada? O muro de Berlim caiu e com ele também a t.d.1.? E o socialismo? Não chegou ao fim? Não seria esta uma teologia marxista, portanto, cabe ainda, neste contexto, escrever de novo sobre ela? Certamente muitos gostariam de ter uma resposta afirmativa para estas perguntas. Aliás, já se anuncia o funeral da t.d.l. há muitos anos. Em 1990 Jon Sobrino, em depoimento dado em torno do assassinato brutal de seus seis companheiros, mais a empregada e a filha, constatava: "E o que me pergunto é sobre que há de tratar a teologia se ignora o fato fundamental da atual criação de Deus; como vai chamar-se a si mesma de 'cristã' uma teologia que passa por alto a crucifixão de povos inteiros e sua necessidade de ressurreição, ainda que em seus livros continue falando de um crucificado e ressuscitado de vinte séculos atrás. Por isso, se aqueles que estão fazendo teologia da libertação não estão fazendo 
bem, que outros façam melhor. Mas alguém tem de continuar a fazê-la. E, pelo amor de Deus, não se diga que ela está fora de moda".

Certamente se houve um funeral, não foi da t.d.1.. Talvez ela esteja em uma catacumba aguardando o melhor momento para se reapresentar a Igreja e ao mundo. E o momento está chegando. E ela sairá da catacumba renovada, ciente dos seus limites, mas fortalecida de suas convicções fundamentais, e não menos profética, como deve ser toda e qualquer teologia. A t.d.l. ainda está no coração de muitos que aprenderam a amar este tipo de reflexão sobre Deus e, diante do mundo globalizado de hoje, anseiam por voltar, humildemente, a pronunciar uma palavra sobre a fé cristã vivida no meio desta realidade.

É preciso lembrar também que a t.d.l nunca foi formalmente condenada pelo Magistério Católico. Em duas instruções, ${ }^{2}$ foi avaliado um modo de fazer t.d.l. e não todo e qualquer modo. O Magistério recomendou que não se usasse o marxismo. O Papa João Paulo II, em carta enviada aos bispos do Brasil através da II ${ }^{\mathrm{a}}$ Instrução disse: "Na medida em que se empenha por encontrar aquelas respostas justas - penetradas de compreensão para com a rica experiência neste País, tão eficazes e construtivas quanto possível e ao mesmo tempo consoantes e coerentes com os ensinamentos do Evangelho, da tradição viva e do perene Magistério da Igreja - estamos convencidos, nós e os senhores, de que a teologia da libertação é não só oportuna, mas útil e necessária. Ela deve constituir uma nova etapa

\footnotetext{
${ }^{1}$ SOBRINO, Jon, Os seis jesuitas mártires de El Salvador. São Paulo: Loyola, 1999, p. 62.

${ }^{2}$ Cf., CONGREGAÇÃO PARA A DOUTRINA DA FÉ, Instrução sobre alguns aspectos da Teologia da Libertação. 2. ed., Petrópolis: Vozes, 1986; e a Instrução sobre a liberdade cristã e libertação. Petrópolis: Vozes, 1986. Daqui para frente vamos nos referir a estes documentos como I Instrução (sobre alguns aspectos da "Teologia da Libertação") e II I Instrução (sobre a liberdade cristã e libertação).
} 
- com estreita conexão com as anteriores - daquela reflexão teológica iniciada com a tradição apostólica e continuada com os grandes padres e doutores, com o Magistério ordinário e extraordinário e, na época mais recente, com o rico patrimônio da Doutrina Social da Igreja, expressa em documentos que vão da Rerum Novarum a Laborem Exercens". 3

Queremos, com este artigo, justamente apontar para a necessidade urgente de continuar fazendo t.d.1. As intuições dessa teologia continuam válidas. Se o Magistério vê com preocupação uma teologia com fundo marxista, então não se use tal mediação. Porém, a necessidade de viver o Amor de Deus nunca se encerrará. ${ }^{4}$ Em toda e qualquer realidade sócio-cultural o cristianismo necessitará dar testemunho deste amor. O Papa Paulo VI disse, no n ${ }^{\circ} .20$ da Evangelli Nuntiandi, que é necessário levar o Evangelho até as raízes da cultura e que existem laços profundos entre evangelização e promoção humana ( $\left.n^{\circ} .31\right)$. Por 6 vezes o Papa vai enfatizar a necessidade do testemunho ( $\mathrm{n}^{\text {os }} 6,15,21,26,41$, e 76$)$, que é a expressão concreta do amor. Ora, a intenção da t.d.l. foi, e é, antes de mais nada, dar testemunho, através também da reflexão, deste mesmo amor. Portanto, se houve erros, corrija-se. Mas, não deixemos de buscar uma teologia que nos ajude dar um testemunho mais coerente.

A dimensão profética, que toda e qualquer reflexão teológica precisa ter, ${ }^{5}$ mais do que nunca, faz-se necessária em nossos dias. $\mathrm{O}$ mundo globalizado mantém injustiças gritantes, e o cristianismo não pode se calar. Quem acredita em Deus, mesmo ciente de que a vida plena não se

\footnotetext{
${ }^{3}$ CNBB, II Instrução, Carta do Papa sobre a missão da Igreja e a Teologia da Libertação, p. 91.

${ }^{4} \mathrm{O}$ nosso Papa atual, Bento XVI, demonstrou muito bem esta necessidade na Encíclica "Deus é Amor".

${ }^{5}$ FORTE, Bruno, nos apresenta bem esta dimensão no livro: Teologia como Companhia, Memória e Profecia. São Paulo: Edições Paulinas, 1991.
} 
esgota em nossa história, deve procurar lutar contra o pecado e realizar sinais daquela salvação realizada por Deus em Jesus Cristo desde já.

Assim, este artigo quer apontar para a necessidade de continuar fazendo uma teologia que indique pistas para manter fidelidade ao Caminho de Jesus Cristo no interior da historia. Obviamente sem a pretensão de propor um único método reflexivo, mas lembrando que a t.d.1 ainda tem lugar no campo teológico. Chamaremos esta continuidade da t.d.l. de Teologia Espiritual da Libertação (T.E.L). ${ }^{6}$ Intuição que encontramos, sobretudo, em Gustavo Gutiérrez, no livro Teologia da Libertação, uma das primeiras obras da t.d.1, mas também em outros autores que trilharam o mesmo caminho teológico, como Jon Sobrino e Clodovis Boff.

Para realizar o objetivo traçaremos 3 itens que indicarão elementos que podem nortear a proposta a ser devolvida por qualquer um que achar relevante tal proposição. Nosso objetivo é propor a continuidade do debate. Não podemos propor um cristianismo vinculado a comportamentos que vão em direção contrária a princípios de vida deixado por Jesus Cristo. Não podemos nos render as expressões religiosas que se confundem com consumismo, individualismo, correndo o risco de confundir o Evangelho com mercadoria. Mas, para tanto, acreditamos que as categorias conceituais sob as quais a teologia cristã foi constituída precisam de um aperfeiçoamento. É nesta direção que este artigo pretende apontar.

\footnotetext{
${ }^{6}$ Realizamos uma fundamentação mais rigorosa em tese doutoral, não publicada, defendida em 1998, na PUC/RJ, com o seguinte título: SERVA DE DEUS E PROMOTORA DA VIDA - Construção de uma teologia espiritual da libertação a partir do debate metodológico da teologia latino-americana, orientada pelo professor Alfonso Garcia Rubio. Os anos se passaram e continuamos a pensar que não se pode deixar perder as intuições da t.d.l. É preciso voltar a escrever sobre elas (debater e construir)..
} 


\section{Razões para propor uma Teologia Espiritual da Libertação (T.E.L.)}

"A teologia é filha da história", ${ }^{7}$ fruto da reflexão de cristãos que, animados pela fé em Jesus Cristo, sentiram-se interpelados pelos desafios do mundo. É fácil verificar que no cristianismo a proposta escatológica não se esgota em um futuro cronológico, pois vai na direção de uma plenificação na eternidade. Mas, também não se pode deixar de verificar que a esperança escatológica é resposta às interpelações e angústias que brotam do viver humano no interior da própria história. $\mathrm{E}$ essa história concreta que sempre desafia a experiência de fé.

Neste início do terceiro milênio, constatamos que os desafios continuam a existir e devem ser enfrentados, e a teologia não pode passar à margem deles. Por isso, mesmo correndo o risco de afirmar o óbvio, em relação ao muito do que já se escreveu em torno desses desafios, vamos nos confrontar com os mesmos, pois, para nós, eles formam a base das reflexões a serem indicadas neste artigo e confirmam a necessidade de uma T.E.L.

Poderíamos listar uma série de problemas hodiernos que provocam um posicionamento da reflexão teológica. Mas, escolhemos apenas três que, a nosso ver, estão mais próximos da temática a ser desenvolvida neste estudo. Apresentaremos primeiramente a questão do sofrimento humano, sobretudo o inocente, em seu aspecto existencial e estrutural. A seguir trataremos de modo bastante rápido, a problemática suscitada pela cultura moderna, isto é, o eixo moderno fundamental que continua a predominar, mesmo que se admitam pós-modernidades ou hipermodernidades. E por fim, faz-se necessário constatar que a teologia tem dialogado pouco com outras ciências e saberes. Cada vez mais

\footnotetext{
${ }^{7}$ FORTE, Bruno, A teologia como companhia, memória e profecia, p. 127. Neste livro o autor tem várias páginas (74-127) dedicadas à relação entre teologia e história.
} 
se percebe a necessidade de construir conhecimento de forma interdisciplinar, e não apenas sobrepondo um saber ao outro. Não se trata apenas de conhecer o que um outro pensa, mas construir o conhecimento levando em consideração o que outro pensa. Este terceiro aspecto será o eixo de articulação escolhido para descrever a proposta.

O sofrimento é realidade inegável da existência humana. Uma categoria que une toda a raça humana. Por isso, pelo seu caráter inevitável, uma tendência da cultura ocidental é evitar enfrentar a questão. "Para superar a realidade da dor", dizem alguns, "é necessário falar somente de vida, esperança, alegria". "O discurso sobre o sofrimento é melancólico demais", dizem outros. Também a angústia de não encontrar uma resposta definitiva cria uma certa atitude de fuga: "Já que não temos respostas, vamos deixar o problema de lado". Existe ainda atitudes de total resignação e até mesmo de completo desespero em relação ao sofrimento.

Algumas vezes o sofrimento também é relativizado demais através da teologia do pecado original e do livre arbitrio, absolutamente verdadeiras, mas que corre o risco de não acolher os sofredores, pois pode acarretar certa atitude fatalista. A teologia do pecado original e do livre arbítrio dado por Deus pode explicar o porquê do sofrimento, mas não dá conta da angústia que ele provoca no ser humano. ${ }^{8} \mathrm{~A}$ realidade do mal e do sofrimento como conseqüência de um primeiro pecado, pura e simplesmente, não satisfaz enquanto resposta existencial. Tão pouco é uma teologia que consegue despertar no crente a tentativa de buscar superar os sofrimentos provocados pelas estruturas sociais. Cremos que o dilema de Jó continua atual. Para muitos, no âmago da existência, fica também a

\footnotetext{
${ }^{8}$ Uma boa síntese sobre a questão do pecado original pode ser encontrada em: RUBIO, Alfonso G., Unidade na pluralidade. São Paulo: Edições Paulinas, 1989, p. 515-549; K. RAHNER, Curso fundamental da fé. São Paulo: Edições Paulinas, 1989, p. 114-145.
} 
pergunta: "Por que foi dado à luz um infeliz - e a vida àqueles que têm a alma amargurada, que anseiam pela morte que não vem, e a procuram com afinco, como a um tesouro, que se alegrariam por um túmulo e gozariam ao receberem sepultura - ao homem, cuja trilha se apagou, por que Deus o cercou de todos os lados?" (Jó 3,20-23).

Assim sendo, cabe ao cristianismo e a sua teologia continuar refletindo sobre as perguntas levantadas pelo desafio do sofrimento. Sabemos, já foi afirmado, que o sofrimento é inerente à limitação humana. No entanto, as estruturas sociais poderiam cooperar para que o mesmo fosse encarado com mais serenidade. Mesmo em situações de bem estar social deveriam ser criadas condições mais humanas para enfrentar o sofrimento, de tal forma que o sofredor encontrasse a possibilidade do consolo. E não constatamos no mundo atual muita disposição para tanto. Morre-se, em geral, solitariamente em uma UTI de hospital. Morre-se pelo descaso de autoridades. Milhares de pessoas inocentes morrem por causa de guerras que não são suas, ainda causando sofrimento aos que possuem ligação com as vítimas. Portanto, nenhuma ciência, muito menos a teologia, fundada na fé no Deus da vida, deveria esquecer tal realidade.

Vamos ao segundo desafio. Cada vez mais se tem refletido sobre as transformações do mundo sob o impacto da chamada cultura moderna. Nós não pretendemos analisar tal situação em perspectiva histórica, e nem tão pouco fazer abordagens conceituais do que significa cultura moderna, muito menos entrar na questão se agora estamos vivendo uma pós-modernidade. ${ }^{9}$ Queremos apenas apontar para o seu aspecto

${ }^{9}$ Cf. VAZ, Henrique C. de Lima, "Religião e modernidade filosófica", in BINGEMER, Maria Clara L. (org.), O impacto da modernidade sobre a religião. São Paulo: Edições Loyola, 1992; neste artigo o autor trabalha bem a questão histórica e conceptual; também de LIMA VAZ, Escritos de filosofia - problemas de fronteira. São Paulo: Edições Loyola, 1986; e AZEVEDO, Marcello de C., Modernidade e Cristianismo, São Paulo: Edições Loyola, 1981; que dá um enfoque antropológico-cultural dos ter- 
desafiante no que tange à vida cristã inserida nesta cultura. E, no interior desta cultura, a teologia é apenas mais uma resposta. Queremos perceber o seu caráter problemático para o fazer teológico, pois não há dúvida de que a modernidade trouxe implicações profundas, de um modo geral, para a vida planetária. A teologia não pode ficar à margem dessas implicações. O impulso dialogal dado pelo Concílio Vaticano II deve ser aprofundado, pois a atitude da Igreja, e, consequentemente, da teologia, até este Concílio, foi, predominantemente, de repulsa ao moderno. Após o Vaticano II, a Igreja tem procurado responder, com mais diálogo, aos desafios deste novo paradigma cultural. No entanto, cremos que ainda existem perspectivas desafiantes para a teologia que não foram devidamente aprofundadas, e cabe a ela procurar o aprofundamento, e neste sentido, ajudar a Igreja no seu caminho evangelizador.

Para exemplificar, podemos mencionar, entre tantos aspectos, o fato de que a racionalidade moderna trouxe consigo a possibilidade de crítica ao fenômeno religioso que no passado era menos freqüente. Como é sabido, houve, sobretudo nos séculos XIX e XX, pensadores que marcaram a história da cultura moderna com críticas à religião que não podem ser banalizadas. Lembremos, entre eles, F. Feuerbach, K. Marx, F. Nietzche e S. Freud. Embora já se tenham produzido muitos trabalhos críticos em torno desses nomes, diríamos que suas colocações continuam, sob muitos aspectos, relevantes. A teologia não deve se fazer surda frente à possibilidade de ser legitimadora, de fato, de uma prática religiosa cristã que dê margem à percepção de um Deus como projeção dos desejos de perfeição humana - Feuerbach. Nem discordar completamente de que, algumas vezes, a prática da fé cristã, como de

mos "cultura" e "moderno" na perspectiva da inculturação. Pessoalmente creio que o termo "neo-modernidade" seria mais significativo, pois "pós" dá a impressão de superação da modernidade enquanto, na verdade, o eixo fundamental continua o mesmo. 
qualquer outra religião, pode ser passível de manipulação alienadora - Marx. Que o contra-testemunho cristão pode apontar para uma ilusão irracional - Nietzche. ${ }^{10} \mathrm{E}$ que, finalmente, é possível encontrar situações na qual exista uma tendência para o aprofundamento de certas patologias psíquicas no fiel cristão - Freud. Tais pensadores, mesmo sendo ateus, de certa forma têm uma dimensão profética, pois suas colocações denunciam condições reais, ainda que não devam ser admitidas integralmente, de uma prática religiosa desumanizadora. Por isso, podemos dar a eles o título de Profetas sem Deus. Diante da crítica dos Profetas sem Deus, pessoas de fé não devem temer dialogar com suas argumentações. Ao contrário, devem se colocar no meio do debate, procurando travar um diálogo no qual não se tomem, a priori, as suas posições apenas como alvo de condenação. Este diálogo faz parte do desafio trazido pela cultura moderna. ${ }^{11}$

Frente aos problemas humanos atuais a palavra teológica levanta muitas questões. Tenta-se dialogar com o mundo tendo em vista a sua salvação. Mas, o diálogo já produziu muitas perspectivas, tornando o trabalho teológico bastante árduo, ainda mais em se tratando de um diálogo feito sob muitas tensões. Torna-se cada vez mais necessário delimitar bem a relevância e a pertinência de qualquer trabalho que se insira nesta realidade. Aqui já nos encontramos no início do terceiro desafio.

Ao longo dos primeiros séculos de nossa era a teologia procurou dialogar com os saberes que norteavam os esquemas mentais da

\footnotetext{
${ }^{10} \mathrm{O}$ Papa Bento XV, na encíclica anteriormente citada, procura dialogar com Nietzche.

${ }^{11}$ Uma revista de grande circulação no Brasil, ÉPOCA, da Editora Globo, publicou um artigo com o seguinte título: A igreja dos novos ateus, no qual apresenta a posição de três renomados cientistas que publicaram livros que falam diretamente contra a fé e a religião com argumentos científicos. Certamente argumentos que podem ser refutados, mas em outro tempo esses senhores não fariam tanto sucesso. (Época, $n^{\circ} .443$, 12 de novembro de 2006).
} 
cultura onde o cristianismo se desenvolvia. Como o saber filosófico predominava na formulação do conhecimento, era natural que a teologia tomasse por base o diálogo com os pensadores que foram determinantes na construção do pensamento filosófico, como, por exemplo, Platão e Aristóteles. Porém, a teologia não pode tomar o pensamento filosófico como um dado revelado. A teologia surge depois de uma experiência: o encontro com a pessoa e a mensagem de Jesus Cristo. Portanto, a fé é o ponto de partida. Ora, assim sendo, torna-se necessário levar em consideração todos os elementos que configuram uma experiência de fé.

O teólogo francês M. D. Chenu dizia: "Não existe uma fé pura". ${ }^{12}$ Portanto, é necessário verificar os elementos humanos que configuram as opções e atitudes tomadas por aqueles que têm fé. Assim sendo, a teologia precisa dialogar com todas as formas de conhecimento que ajudem a entender melhor a experiência na qual a fé é realizada. Aceitar a Revelação não significa ter desconsideração para com os fatores que circunscrevem a aceitação da mesma. E entre esses fatores se encontra o modo pelo qual o ser humano processa conhecimento. Esta é a terceira razão que nos empurra para buscar uma reflexão teológica em condições de dialogar com os procedimentos atuais de configuração do saber. Por isso, vamos trabalhar, no próximo item, este desafio, como um elemento fundamental para a construção de nossa proposta.

\section{Traços epistemológicos elementares para uma T.E.L.}

Percebemos hoje a necessidade de uma reconstrução conceitual da teologia. A teologia cristã é um saber muito antigo no mundo oci-

${ }^{12}$ CHENU M. D., Carta-proemio, in VILANOVA Evangelista, Para compreender a teologia. São Paulo: Edições Paulinas, 1998, p. 71. 
dental, sendo superado apenas pela filosofia. Quando formas modernas de conhecimento como a sociologia, a antropologia, a psicologia e a economia, por exemplo, estavam se organizando, o saber teológico já se articulava, em bases filosóficas, desde longa data. Então, como poderíamos propor uma reconstrução diante de um edificio que tem uma história arqueológica e que apresentou ao mundo nomes, entre tantos, como Agostinho de Hipona, Tomás de Aquino, Martinho Lutero, Francisco Suaréz, Rudolf Bultmann e Karl Rahner? ${ }^{13}$ Seria possível deixar de lado toda a teoria do conhecimento que deu suporte à teologia durante séculos e fundamentou a elaboração de diversos dogmas?

Inegavelmente, qualquer teólogo cristão que se atreva a trilhar este caminho desafiante deverá estar ciente do necessário recurso ao passado. Não se faz teologia sem memória. Assim sendo, quando indicamos uma necessária reconstrução de alguns fundamentos teológicos, parece que estamos acometidos de um atrevimento sem igual. Porém, o atrevimento é só aparência. Não temos, de fato, a mínima condição de dar cabo de tarefa tão grandiosa, ainda mais em um artigo. Mas, podemos propor a mudança de alguns procedimentos, que certamente apontarão para possíveis reformulações conceituais mínimas.

Para verificar a necessidade apontada acima, apresentaremos um exemplo da prática pastoral. - O presente redator trabalha, há muitos anos, com a formação do laicado -. Deparamo-nos com a problemática de capacitar, através da formação teológica, cristãos e cristãs para a missão de evangelizar. Uma das maiores dificuldades é articular as categorias gregas, sob a qual boa parte do cristianismo foi estruturada ${ }^{14}$. E, não pode-

\footnotetext{
${ }^{13}$ Certamente que a lista apresentada acima poderia ser bem maior. Mas, procuramos citar alguns poucos nomes, entre católicos e protestantes, já falecidos, que deixaram uma contribuição teológica que influenciou, e continuam a influenciar, muitas concepções teológicas. ${ }^{14}$ SEGUNDO, J. Luís, fazendo uma colocação quanto à inculturação em torno da filo-
} 
mos concordar com críticas preconceituosas que identificam a dificuldade de assimilação em fatores étnicos e biológicos do povo latino-americano. Preconceito que se dirige a quase todos os povos de Terceiro Mundo. Se esta explicação etnocêntrica não pode ser aceita, onde estaria o núcleo da dificuldade? Suspeitávamos que nos procedimentos de elaboração da reflexão teológica havia um muro que separava a racionalidade da experiência de fé. Então, na t.d.1., encontramos, inicialmente, um caminho de solução. Mas, a t.d.l. se tornou uma solução insuficiente, pois mesmo ela não apresentou uma dinâmica cognitiva capaz de ir ao encontro do esquema mental daqueles que ela busca servir: os pobres. No entanto, ao mesmo tempo, algo nos dizia que a t.d.l. vislumbrou uma resposta, porém não conseguiu desenvolvê-la a contento. Gustavo Gutiérrez afirma no livro Teologia da Libertação que uma das tarefas da teologia é ser teologia espiritual. Porém, muito pouco foi desenvolvido.

A t.d.1. costuma apresentar, como condição do conhecimento teológico, uma ruptura epistemológica ${ }^{15}$, presente desde a Sagrada Escritura, como expõe Jon Sobrino ${ }^{16}$, e que implicaria na incorpora-

sofia grega, observa o seguinte: "No entanto, dentro da Igreja, a filosofia - considerada 'perene' - mantém-se por via autoritária. Ainda é a que se ensina à maioria dos futuros teólogos católicos. E, desse modo, apesar de não convencer, a síntese criada no mundo medieval continua marcando, pesadamente, o pensamento que se cria dentro da Igreja católica, até nossos dias, com seu monismo vergonhoso, por assim dizer", Que Mundo? Que Homem? Que Deus? - Aproximações entre ciência, filosofia e teologia. São Paulo: Paulinas, 1995, p. 91.

${ }^{15}$ Conceito moderno introduzido por G. BACHELARD. Embora não tenhamos feito contato direto com a obra de Bachelard, cremos que o livro de H. JAPIASSU, Introdução ao pensamento epistemológico. 3. ed. Rio de Janeiro: Francisco Alves Editora, 1979, fundamenta o que foi dito acima.

${ }^{16}$ Cf., SOBRINO, J. , A ressurreição da verdadeira Igreja. São Paulo: Loyola, 1982, sobretudo o capítulo 1: "O conhecimento teológico na teologia européia e latino-americana", pp. 17-47, especialmente na p. 35, na qual afirma o seguinte: "A leitura da Escritura mostra que não existe conhecimento teológico sem esta ruptura epistemológica. Mas na Escritura, a ruptura aparece de duas formas: 1) enquanto afirma a trans- 
ção de um conhecimento dialético em contraposição ao uso exclusivo do conhecimento analógico, enfim, um conhecimento que não permaneceria na posição da admiração grega. Contudo, ao nosso entender, para se ter na ruptura um elemento capaz de produzir conhecimento, é necessário uma condição anterior: a compreensão dos processos pelo qual o conhecimento é elaborado e a busca de adequação daquilo que se pretende compreender com aquilo que se vive e se experimenta no interior de um processo cultural.

Então, levando em consideração o que acaba de ser afirmado, entendemos a reconstrução de alguns fundamentos teológicos como um procedimento teórico-prático necessário para realizar uma reflexão teológica em sintonia com a realidade atual. Naturalmente, devido á longevidade da teologia, ela tem dificuldade de mudar os procedimentos de sua construção teórica, pois teme não ser fiel, com os novos procedimentos, à Revelação. Ora, certamente é esta uma tarefa agigantada. Portanto, é compreensível que os teólogos da libertação também fizessem um desvio no enfrentamento da mesma. Mas, cremos que aí está o problema principal. Sem retomarmos, significativamente, temas como fé, revelação e salvação, por exemplo, fica complicado propor uma teologia alternativa, uma teologia com capacidade real de diálogo com os paradigmas atuais. O que se tem feito, predominantemente, em nossos dias, é sobrepor duas lógicas distintas: a lógica filosófica sobre a qual os conceitos teológicos se desenvolveram e a lógica das ciências humanas e sociais sob a qual se pretende dar relevância para a teologia hoje. Com sobreposição não se resolve o problema, pois se fica em um paralelismo que não se cruza, que não se interpela mutuamente.

cendência de Deus como futuridade, o conhecimento teológico deve ser distinto do conhecimento natural. 2) enquanto afirma a transcendência de um Deus crucificado, o conhecimento teológico deve ser contrário ao conhecimento natural". 
Qual seria, então, o melhor caminho para ajudar alguém a fazer um processo de aprendizagem que, ao mesmo tempo, estabeleça uma estrutura mental capaz de fornecer à pessoa condições de integração entre a experiência racional e a existencial? Evidentemente que não pretendemos criar uma resposta acabada para tal questão, mas sim apontar perspectivas.

Não se chega à verdade, sem a participação no processo que conduz à verdade, sem perceber a gênese epistemológica que dá ao sujeito do conhecimento um caminho de intelecção. Sem um caminho próprio de intelecção se fica em pura memorização de definições, como em um catecismo de pergunta e resposta no qual se decora sem entender. E, neste campo, tomamos como referência a contribuição de Jean Piaget. ${ }^{17}$ Piaget não pode ser visto apenas como um especialista em epistemologia infantil. Seu trabalho não se restringe apenas à psicologia e a pedagogia, mas pode ser estendido, sem dúvida alguma, a vários campos do saber. Por isso, vamos dialogar com ele. Trata-se, de um uso bastante flexível, feito com muita liberdade.

${ }^{17}$ Cf., do próprio J. PIAGET, A epistemologia genética / Sabedoria e ilusões da filosofia. 2. ed. São Paulo: Abril Cultural - Coleção Os pensadores, 1983; id, O desenvolvimento do pensamento. Lisboa: Publicações Quixote, 1977; e Biologia e conhecimento. 2. ed. Petrópolis: Vozes, 1996; comentários: Lauro de Oliveira LIMA, Piaget, sugestões aos educadores. Petrópolis: Vozes, 1999. Bárbara FREITAG (org.), Piaget, 100 anos. São Paulo: Cortez Editora, 1997; Hans G. FURTH, Piaget e o conhecimento. Rio de Janeiro: Forense Universitária, 1975; Antônio M. BATTRO, O pensamento de J. Piaget. Rio de Janeiro: Forense-Universitária, 1976; Maria da Graça AZENHA, Construtivismo de Piaget a Emília Ferreiro. São Paulo: Ed. Ática, 1993; e o livro de H. JAPIASSU, op. cit., p. 41-60, que contém um capítulo sobre Piaget: "A epistemologia genética de J. Piaget”. Estes livros nos serviram de fundamentação para a construção do item que está sendo desenvolvido por acima. O nosso uso se dá na assimilação de algumas idéias encontradas nestas obras e não de modo a fazer uma aplicação direta de tudo que elas contêm. Nem temos tão pouco a intenção de fazer uma síntese do pensamento de Jean Piaget. 
Contudo, a interdisciplinaridade, defendida por Piaget, permite-nos este uso. Também estaremos levando em consideração um elemento pouco ressaltado por Piaget, isto é, que as estruturas do desenvolvimento do conhecimento estão intermediadas pelas relações humanas vividas num contexto sócio-cultural.

Para ilustrar um pouco melhor o que foi dito, tomemos uma área na quais as pesquisas piagetianas são bastante utilizadas: a alfabetização como exemplo de que o conhecimento só se processa se existir uma integração entre o sujeito que conhece e o objeto do conhecimento. No Brasil, em geral, os métodos tradicionais de alfabetização tratam as crianças como se fossem uma caixa vazia na qual se depositará a linguagem escrita, fato que deve ser semelhante em outras realidades. Passam-se os anos, e as mesmas pessoas que tratavam as crianças como caixas vazias se lamentam pela falta de motivação dos adolescentes e jovens para a leitura. As referidas pessoas não percebem que a falta de motivação tem sua origem já no início do processo de alfabetização. Trata-se o sujeito do conhecimento como se fosse um sujeito passivo, e o erro não é compreendido como parte de um processo no qual o sujeito vai elaborando a sua estrutura mental. Assim, o sujeito não é estimulado a assumir como seu o processo de conhecimento. O conhecimento se torna apenas aquilo que eu devo adquirir de um outro. Ora, para que isto não aconteça é necessário ter uma atitude construtivista. ${ }^{18}$

A atitude construtivista levou, aos que assumiram esta epistemo-

\footnotetext{
${ }^{18}$ Atitude construtivista é uma forma simplificada para apontar na direção de uma postura que aquele ou aquela que se coloca na função de $\operatorname{professor}(a)$ deve ter em relação à ajuda que pode oferecer ao aluno. Trata-se de uma interação que ajude a construir o conhecimento na realidade cognitiva daquele que aprende, e não simplesmente uma memorização das idéias do(a) professor(a).
} 
logia evidentemente, a uma mudança de posição em relação aos métodos tradicionais de alfabetização. $\mathrm{Na}$ atitude construtivista a pessoa que aprende é um sujeito epistêmico, isto é, um sujeito que interage na experiência cognitiva, e que através da adaptação, assimilação, acomodação e organização de seus processos cognitivos constrói o conhecimento. E a mudança tem configurado, como se pode constatar em diversas experiências construtivistas que aqui não nos cabe relatar, a possibilidade de montar um quadro conceitual que aponta para uma nova realidade no processo de conhecimento. E o que é mais surpreendente e libertador, trabalha-se também com aqueles que, muitas vezes, são considerados mentalmente incapazes de conhecer, como os chamados excepcionais (pessoas com Síndrome de Down). Hoje se discute inclusive, em educação, para a necessidade da não criação de salas especiais para estas pessoas.

Alguns poderiam objetar que o construtivismo é uma atitude epistemológica válida somente para crianças, o que seria um absurdo, pois seria admitir uma verdadeira metamorfose entre a fase infantil e fase adulta. Seríamos, praticamente, outro tipo de ser na fase adulta. É obvio que a estrutura fundamental se forma na infância, Piaget provou isto. Porém, muito do que se observa nesta fase continua pela vida. Então, continuando ainda com o exemplo de alfabetização, agora se referindo aos adultos, parece que os princípios piagetianos não perdem o seu valor. No Brasil, o melhor exemplo, é sem dúvida a proposta pedagógica de Paulo Freire, falecido em 1997. Embora, em relação aos adultos, não se fale tanto de construtivismo, mesmo porque, quando o que se convencionou chamar "Método Paulo Freire de alfabetização" foi implementado no Brasil (com mais força na década de 60), o construtivismo 
era pouco debatido ${ }^{19}$, assim pode-se identificar uma posição semelhante do Método Paulo Freire com os princípios piagetianos.

Se, em relação às crianças, não se pode partir do princípio que elas são caixas vazias, quanto mais com os adultos. E Paulo Freire percebeu muito bem que o ato de conhecimento pode se tornar um ato libertador e não apenas uma ilustração ${ }^{20}$. Em muitos núcleos de alfabetização de adultos no Brasil se constatou uma realidade cognitiva extremamente importante: adultos que não aprendiam ou tinham muita dificuldade para desenvolver a linguagem escrita, logo que para eles esta linguagem, lida e escrita, passou a representar a possibilidade de ler a vida com mais um instrumento, os progressos foram significativos. A partir de um processo no qual o adulto, muitas vezes com as mãos tão calejadas pelo trabalho que mal se consegue segurar um lápis, pôde vislumbrar um mundo onde ele é parte integrante, um mundo onde a escrita não é apenas um código a ser decifrado, muda a expectativa em relação ao futuro. Percebe-se, neste processo, que a inteligência humana é algo tão rico que não pode ser enclausurada por nenhuma concepção de verdade. Em vista disto, Paulo Freire nos ensinou que a ciência é um saber que só pode ser feito com humanidade se unir os dois elementos que constituem a vida em sua estrutura cognitiva: teoria e prática, razão e afeto. ${ }^{21}$

${ }^{19}$ Cf., BRANDÃO, Carlos Rodrigues, O que é método Paulo Freire. 5. ed. São Paulo: Ed. Brasiliense, 1983.

20 “A educação que Paulo Freire vislumbra não é apenas politicamente utilitária. Ela não objetiva somente criar novos quadros para um novo tipo de sociedade. Há uma proposta politicamente mais humana, a de criar, com o poder do saber do homem libertado, um homem novo, livre também de dentro para fora", ibid, p. 87.

21 "O processo de saber, que envolve o corpo consciente todo, sentimentos, emoções, memória, afetividade, mente curiosa de forma epistemológica, voltada ao objeto, envolve igualmente outros sujeitos cognoscentes, quer dizer, capazes de conhecer e curiosos também. Isto significa simplesmente que a relação chamada cognoscitiva não encerra na relação sujeito cognoscente-objeto cognoscível porque se estende a outros sujeitos cognoscentes", FREIRE, Paulo, Professora sim, tia não - cartas a 
Assim, em torno do exemplo sobre o processo de alfabetização, que procurou demonstrar através de uma questão concreta, as razões de nossa opção construtivista, queremos sustentar que as bases epistemológicas para a reconstrução de alguns fundamentos teológicos podem ser colocadas sobre o pressuposto de que o conhecimento teológico é uma reflexão humana feita por elementos cognitivos construídos pela experiência sócio-cultural, no qual estes elementos são desenvolvidos, e a fé, como parte integrante deste processo, não é um elemento que caminha à margem, mas direciona, articula, indica prioridades e rejeita, a priori, concepções que não proporcionariam a manutenção dos dados imprescindíveis à existência da mesma fé.

Um conhecimento teológico feito, estritamente, em bases epistemológicas que rejeitem o caráter construtivista do conhecimento, tenderá a elaborar uma conceituação circunscrita em dois mundos paralelos: o mundo de uma teologia elaborada com critérios rigorosamente teórico-científicos, feita e entendida somente por especialistas; e o mundo da experiência de fé, da experiência religiosa, que não alcança as explicações teológicas cientificas, podendo até entender um mesmo princípio da fé de modo diverso ao da teologia científica considerada ortodoxa (Ex.: entender ressurreição como reencarnação, ser subordinacionista ou trideísta em relação à Trindade, colocar Maria Santíssima como uma deusa feminina, etc.). Este segundo mundo não é pesquisado ou estudado, mas tolerado. Como é um mundo que não escreve livros e não tem repercussão pública, não causa problema.

Então, como poderia a teologia articular a sua estrutura de elaboração e sustentação da racionalização da fé sem que corra o risco de menosprezar a própria experiência de fé que pretende racionalizar?

quem ousa ensinar. São Paulo: Editora Olho D’água, 1993, p. 122. 
O que significa racionalizar a fé? Com que tipo de saber deveria a teologia dialogar para tentar superar o divórcio entre teologia e espiritualidade que, a nosso ver, tem sido a principal causa dos problemas eclesiais hoje constatados? Tomando o conhecimento como uma realidade construída por diversos fatores que perpassam a realidade humana, pretendemos, a seguir, aprofundar este elemento epistemológico no interior do processo de reflexão teológica.

\section{Configuração básica e elementar de uma T.E.L.}

Para apontar a possibilidade de fazer uma T.E. L, vamos defender um processo de elaboração teológica no qual se tomem três aspectos da construção do mesmo:

a) A teologia como saber sistemático;

b) A teologia como saber espiritual;

c) A teologia como saber espiritual-libertador.

Pode existir um saber espiritual que seja reconhecido como reflexão sistemática e metódica? O que é um saber espiritual cristão? É necessário dar ao saber teológico um caráter libertador? Trabalhemos então, no limite deste artigo, a resposta a tais perguntas:

a) A teologia é um saber elaborado de forma sistêmica. Disso não há dúvida. É um saber sistemático, organizado e metódico que parte da fé e a ela deve voltar, onde o processo de construção conceitual deve se caracterizar por uma estrutura que leve em consideração a experiência humana cognitiva na qual a fé se dá. A posição assumida neste artigo poderia ser interpretada como uma descaracterização da 
cientificidade teológica. Aqui se entra no já longo debate sobre se a teologia é ciência ou de como a teologia é ciência ${ }^{22}$. Sem pretender banalizar a questão, logo se observa, em torno dessa discussão, que, no contexto atual, há necessidade de um enorme esforço para demonstrar a cientificidade da teologia ${ }^{23}$. É preciso primeiro definir o que é ciência para depois encaixar a teologia na definição que não excluiria a mesma de ser considerada ciência. Ora, é necessário, de fato, todo esse esforço cognitivo para garantir cientificidade à teologia? A nossa posição, ao não realizar semelhante esforço, coloca a teologia como um saber de $2^{\mathrm{a}}$ ou $3^{\mathrm{a}}$ categoria?

Teologia, em definitivo, versa sobre uma relação: aquela entre seres humanos e Deus. E no caso da teologia cristã, Deus revelado em Jesus Cristo. Mas, Deus não pode ser percebido em si mesmo, e isto não nega a relação. Negá-la seria negar um fato social: religiões. Deus está em uma realidade relacional na qual bilhões de seres humanos se encontram. Outros poucos milhões de seres humanos não possuem essa relacionalidade, mas este fato não nega a experiência de quem trava uma relação com o divino. A experiência é objetivável. E negar este tipo de experiência não significa afirmar a impossibilidade de realizar, para os que negam, um encontro relacional com o absoluto, mesmo que este absoluto não seja reconhecido como divino. Certa visão metafísica é subjacente a qualquer visão de mundo ${ }^{24}$, isto é, todo ser humano, inclusive o cientista, encontra-se

\footnotetext{
${ }^{22}$ No livro de J.B. LIBÂNIO, \& Afondo MURAD, Introdução à teologia, perfil, enfoques, tarefas. São Paulo: Edições Loyola, 1996; no capítulo "Conceito e natureza da teologia”, pp. 57-109, encontra-se uma ampla abordagem sobre a questão.

${ }^{23}$ Cf, RAHNER, K., Teologia e ciência. São Paulo: Edições Paulinas, 1971.

${ }^{24}$ Sobre isto ver o importante trabalho de J. Luís SEGUNDO, Que mundo? Que homem? Que Deus?. Entre, outras afirmações, destacamos a seguinte: "O positivismo quis construir uma ciência sem 'ontologia'. Ou talvez, poder-se-ia dizer, com a menor
} 
sob o imperativo de algum tipo de fé que the conduz a existência e desenvolve opções, inclusive científicas. Mesmo que seja uma fé imanente. É aqui que a teologia encontra sua legitimidade. Ao lado da filosofia, a teologia procura o sentido da vida humana tendo em vista uma experiência de fé originante, e, ao mesmo tempo, ela procura coadunar o sentido com um caminho de vida que esteja sintonizado com os valores descobertos e aprofundados na história como revelação de Deus. Como são valores históricos, a teologia deverá também aprofundar as circunstâncias que constroem a história. Certamente, se temos fé, tudo que se passa debaixo do sol será passível de teologização, como dizia Santo Tomás ${ }^{25}$. Contudo, pretender falar de tudo correta e coerentemente é, ao mesmo tempo, falar de nada,

dose possível de metafísica. Daí que, queira ou não, goste ou não goste Monod, a influência determinante da finalidade na esfera biológica faz com que as perguntas sobre o 'para que...' se acumulem numa escalada que ameaça terminar com o perguntar que sentido ou finalidade pode ter o universo inteiro. E daí à pergunta pelo Criador não há mais que um passo... E este é o paradoxo: a teoria da evolução biológica, nascida como uma hipótese radicalmente oposta à da criação, transforma-se agora em algo perigosamente próximo dela. De fato, aquilo que, no mundo 'inanimado' parece estar regido pelo puro acaso, como diz Monod, entra numa 'evolução', onde a 'necessidade' substitui-se ao acaso, colocando diante dos acontecimentos uma flecha indicadora de uma direção necessária”, p. 20-21.

25. "Deus é o objeto desta ciência, porque o objeto está para a ciência como para a potência ou hábito. Ora, propriamente, é considerado objeto de potência ou hábito aquilo sob cujo aspecto se lhes refere qualquer coisa. Donde, referindo-se à vista, enquanto coloridos, o homem e a pedra, é a cor o objeto próprio da vista. Ora, a sagrada doutrina tudo trata com referência a Deus, por tratar ou do mesmo Deus ou das coisas que lhe digam respeito, como princípio ou fim. Pelo que é Deus, verdadeiramente, o objeto desta ciência - o que também se demonstra pelos princípios da dita ciência, ou artigos da fé, de que Deus é objeto. Ora, idêntico objeto têm os princípios e toda a ciência, por estar última, total e virtualmente, contida nos primeiros. - Certos, porém, atendendo às matérias tratadas e não, ao ponto de vista, a esta ciência assinaram o objeto; a realidade e os símbolos, ou as obras da reparação, ou todo Cristo, isto é, a cabeça e os membros. E, com efeito, são consideradas nesta ciência todas essas matérias, se bem com relação a Deus", Suma teológica, I q. 1 a. 7c. 
pois estaríamos indo longe demais. Seríamos deuses.

A nossa preocupação não é defender a teologia como ciência em si, mas sim mantê-la em condições de dialogar com a vida humana, em harmonia com toda a natureza, e em vários aspectos, inclusive, obviamente, com a descrição científica da vida. Para isso a teologia necessita de organização teórica, porém não para se moldar exatamente segundo os parâmetros das ciências, mas para se afirmar como discurso sobre Deus no interior da realidade histórica. Isto ela pode, humildemente, exigir da sociedade. Teologia não é ciência da religião, e nem ciência de Deus ou da salvação, mas sim um saber sistemático cujo pressuposto fundante é uma experiência de fé que afirma a existência de Deus e crê que Ele se manifesta na história, e se manifestou, especialmente, em Jesus Cristo. Neste sentido, o teólogo J. Ratzinger, quando não era o Papa Bento XVI, resume bem a especificidade da teologia: "Porém, assim como não é possível aprender a nadar sem água, nem aprender medicina sem pessoas doentes, de igual maneira não é possível aprender teologia sem as realizações espirituais das quais vive" 26 .

b) A teologia é um saber espiritual. Teologia cristã e vida espiritual nasceram unidas e foram se separando a ponto de uma não ter nada, ou quase nada, a ver com a outra. Hoje existe um esforço de juntar o que estava separado. Nossa contribuição se circunscreve no bojo desse esforço. Se o pressuposto da teologia é a fé, se afeto não excluí a razão, se a experiência humana condiciona as opções cognitivas, se o conhecimento humano se dá em um processo de construção no interior da biologia humana, a teologia, um tipo de

${ }^{26}$ RATZINGER, J., Teoria de los princípios teológicos. Barcelona: Herder, 1985, p. 388. 
saber, será um saber espiritual, pois esta experiência humana está embutida na construção do conhecimento. $O$ caminho espiritual cristão é o que qualifica a teologia, assim, espiritualidade não é uma disciplina a mais, mas a configuração de um caminho de fé no qual a teologia também estará calcada.

A teologia é um saber espiritual. E isto, sem dúvida nenhuma, a t.d.l. percebeu bem, pois a libertação deve ser feita com espírito. Neste sentido, J. Sobrino e G. Gutiérrez procuram trazer, para dentro da reflexão, o caráter espiritual da teologia. A nosso ver, em seus escritos encontramos pontos de partida que contribuem para o desenvolvimento da t.d.1. como teologia espiritual da libertação, mas que devem ser reestruturados por uma nova atitude metodológica. Mas, somando ao que já se construiu em relação a uma teologia espiritual no bojo da t.d.1., é preciso acrescentar ainda alguns poucos elementos, no entanto de fundamental importância.

Inicialmente é preciso lembrar que a teologia é cristã. E quais as conseqüências deste adjetivo? Se o que pretendemos fazer, através de um labor intelectual, pertence à tradição cristã, significa que o resultado deste labor deve transparecer em um caminho de vida que optou pelo mistério de Deus revelado em Jesus Cristo. É preciso acentuar os elementos mistagógicos, direta ou indiretamente, na própria construção ou desenvolvimento das categorias teológicas. Para tanto a teologia não deve temer assumir uma linguagem mais mística. Uma linguagem narrativa que consiga fazer o mistério brotar no interior da história com imagens fortes. Que seja capaz de comunicar através de uma simbologia que fale ao mundo crente e descrente de hoje. Não era assim que Jesus fazia com suas parábolas? 
Por ser um caminho sistemático, organizado teórica e metodologicamente, a teologia não precisa abrir mão de ser espiritual. Também a Sagrada Escritura, e nela o N.T., não é uma construção teórica? O N.T. é o testemunho concreto de que é possível narrar o Mistério de Deus, com categorias do conhecimento humano, sem deixar que a teoria abafe o encontro entre os seres humanos e Deus. Evidentemente que não vamos fazer uma Bíblia para cada novo tempo. Mas, os Santos Padres também, em grande parte, não conseguiram narrar com força o mistério cristão através da teologia? Como diz B. Forte, na teologia simbólica dos Santos Padres "a inteligência é assumida plenamente no dinamismo da fé, como inteligência crente, pela qual Deus não é somente objeto do conhecimento, mas fonte e termo do amor, que abraça toda a vida" ${ }^{27}$. Sinal de que em cada novo tempo é possível continuar a narrar com beleza e profundidade o encontro entre seres humanos e Deus.

c) A teologia é um saber espiritual-libertador. Recordar o caráter libertador é a grande contribuição da t.d.l. A questão é saber como a dimensão libertadora se articula com a reflexão teológica. $\mathrm{O}$ que tem sido predominante na t.d.l. é tomar o da libertação numa configuração social, política e econômica, na qual se faz necessário a mediação sócio-analítica para não ficar em generalidades sobre a injustiça e a opressão. A "libertação é libertação do oprimido" 28 e "a figura epocal do oprimido no Terceiro Mundo é a do pobre sócio-econômico" ${ }^{29}$. E, toda vez que a opressão e a injustiça social deixam de acontecer para o oprimido é um sinal

\footnotetext{
${ }^{27}$ FORTE, Bruno, A teologia como companhia, memória e profecia, p. 92.

${ }^{28}$ BOFF, C. \& BOFF, L., Como fazer Teologia da Libertação. Petrópolis: Vozes/Ibase, p. 40.

${ }^{29}$ Ibid, p. 41.
} 
da presença do Reino Deus, ainda que o sinal seja envolvido no meio de nossa realidade humana pecadora.

Não negamos, em hipótese alguma, a necessidade de nos posicionarmos em relação à injustiça e a opressão, e que, para tanto, faz-se necessário aprofundar, através de análises complexas, todos os elementos que configuram a realidade social. E, a nosso ver, uma das dificuldades se dá justamente pelo fato de alguns restringirem o conceito de libertação ao elemento sócio-econômico. Então, diante disso, o que estamos propondo é alargar o conceito libertação. Somente assim podemos manter a teologia com uma identidade bem definida. Para nós, a análise da realidade não pertence ao método teológico, mas sim ao diálogo interdisciplinar. Neste sentido o conceito libertação necessita, em teologia, de um complemento: o espiritual. Teologia é um saber espiritual-libertador. Porém, o que isso significa? É bom relembrar que o espiritual da teologia está mergulhado no Mistério Pascal, no seguimento de Jesus Cristo. Portanto, ele jamais poderá tomar um caráter exclusivamente existencial em detrimento do estrutural. Mas, em nossos dias, o conceito espiritual, no campo cristão, é, de fato, passível de ser concebido com uma atitude a - histórica. ${ }^{30}$ Aqui entra em cena um complemento fundamental para manter a coerência com o anúncio da Boa Nova de Jesus: o caráter libertador.

O espiritual indica teologia como um discurso predominante-

30. É interessante como Bruno SECONDIN e Tullo GOFFI constatam bem a realidade observada acima na introdução ao livro Curso de Espiritualidade. São Paulo; Edições Loyola, p. 11: "Infelizmente, é uma imagem clássica da espiritualidade a de ser cultivadora de uma modalidade de estar diante do divino em formas mais solitárias do que solidárias, mas como isolados do que consorciados. Ademais, muitos pensam, ainda hoje, que o retorno à 'espiritualidade' seja um mau sintoma, na medida em que por sua natureza, conduz a 'se exilar da história', promovendo o mundo interior e misterioso de cada um e concentrando suas preferências nas elevações vertiginosas e "no silene perder-se no mar do divino"'. 
mente calcado na experiência de fé cristã, e libertação colocado nas conseqüências de uma teologia enraizada no Mistério Pascal, feita num processo de construção dos conceitos que respeite o caminho de fé que a tradição cristã fez e faz e se comprometa com as conseqüências históricas de suas afirmações.

E uma teologia enraizada no Mistério Pascal se entenderá como da libertação, porque a missão de Jesus Cristo foi libertadora. Mas, a libertação de Jesus leva em consideração a situação do ser humano assim como ele se encontra. A situação de opressão e miséria, em seu caráter estrutural, pela sua gravidade, pode nos levar a passar por cima da situação existencial na qual vivem seres humanos.

Também não podemos esquecer da questão ecológica, que, no entanto, passa por questões políticas. O compromisso político com a transformação das estruturas injustas é uma realidade com a qual todos devem, de alguma maneira, estar comprometidos, mas apenas uns poucos podem, especificamente, envolver-se diretamente, pois a ação política direta é uma vocação e não obrigação. Portanto, o de alguma maneira não significa, necessariamente, tornar-se participante ativo no processo, isto é, com um engajamento em instituições sociais que procuram a transformação social, como os partidos políticos. Uma teologia enraizada no Mistério Pascal lembrará que Jesus foi comprometido, sim, com a realidade histórica. Porém, aquele que segue Jesus Cristo lembrará também que assim como Ele esbarrou com as contradições históricas, especificamente o pecado, obrigando-o a radicalizar o seu amor para com a humanidade, também o nosso seguimento pode exigir que a mediação do amor cristão se faça mediante a dor, a angústia, e o sofrimento de pessoas que vivem a presente história. 
Afirmamos que o da libertação em teologia passa pelo estrutural, mas não se esgota nele. A libertação tem, sem dúvida, uma dimensão macro-estrutural, já tão bem analisada pela t.d.l. Sem dúvida que boa parte do sofrimento da humanidade poderia ser diminuído se as condições de vida digna fossem uma realidade mais abrangente. Contudo, não o é. Portanto, assim como somos unidos, solidariamente, pelo pecado, precisamos nos unir contra o pecado. E cremos que a solidariedade pode penetrar inclusive as estruturas sociais. Neste sentido, a teologia não pode se colocar à margem de um processo no qual ela ajude a pensar uma realidade mais próxima da vontade de Deus para a criação inteira.

Assim sendo, os três aspectos apresentados aqui, certamente, não esgotam as possibilidades de indicar a necessidade e continuidade da t.d.1. Porém, como disse Jon Sobrino, citado na introdução deste trabalho, esse tipo de reflexão não é uma "moda", mas um imperativo diante do pecado humano. É evangélico. É cristão. É católico.

\section{Conclusão}

Com este artigo, na verdade, não pretendíamos concluir nada, mas reabrir um debate. Seria até interessante se ele fosse refutado no que se refere aos elementos apresentados como fundamentação, mas se, ao mesmo tempo, provocasse discussão na direção da continuidade da t.d.1.. Se isto acontecesse, ele teria alcançado o seu principal objetivo.

Estamos vivendo uma situação planetária onde aparentemente existe solução para todos os problemas humanos. E mais: prega-se, como alguns teólogos observam, uma experiência religiosa na qual a mensagem central de Jesus Cristo é pouco relevante. É o que se chama 
de Idolatria do Mercado. Continua a se falar, predominantemente, de Deus. Mas, que Deus? O Deus de Jesus Cristo ou do consumismo no qual deus é apresentado como o legitimador da prosperidade pessoal onde o egoísmo é elevado a virtude principal?

Apesar de todo avanço, as estatísticas continuam a mostrar grandes contradições: $20 \%$ da população mundial consomem $80 \%$ dos recursos naturais do planeta, injusta distribuição da riqueza, fome, miséria, analfabetismo, doenças endêmicas, guerras econômicas, enfim uma gama enorme de problemas que questionam profundamente a qualidade de nossa opção de fé, o nosso testemunho. Como dizia o Papa Paulo VI no nº. 76 da Exortação Apostólica Evangelli Nuntiandi, "Mais do que nunca, portanto, o testemunho da vida tornou-se uma condição essencial para a eficácia profunda da pregação. Sob este ângulo, somos, até certo ponto, responsáveis pelo avanço do Evangelho que nós proclamamos".

As observações feitas na primeira parte do parágrafo anterior poderiam se objetadas como assuntos que não dizem respeito à teologia. Caberia à teologia apenas ajudar a legitimar o caminho para a eternidade. Ora, não é necessário ser teólogo para concluir que não seria esta uma atitude cristã. Se não é cristã, a teologia não pode se resumir a repetir simplesmente a doutrina ou explicá-la melhor, mas buscar uma palavra que se possa com ela propor o caminho cristão como humanizador em todo e qualquer tempo. E ela só fará isto se for capaz de dialogar, sempre de modo renovado, com as expectativas que configuram o agir humano em toda e qualquer época. Portanto, não abandonemos a dimensão profética do fazer teológico. Que o Senhor nos dê coragem e animo para continuar a buscar uma teologia que toque o coração das questões que afetam o viver humano, pois é ai que se podem encontrar os vestígios do Deus de Jesus Cristo, aquele que sendo de condição 
divina não se apegou ciosamente a esta condição, mas esvaziou-se e assumiu a condição de servo (F1 2, 7).

\section{Resumé}

La spiritualité est profondément libératrice. La théologie ne se comprends pas sans cette spiritualité. De cette manière, la vraie théologie se nourrisse d'une spiritualité que libère, transforme et convertisse. La spiritualité de la libération vient à être le vent que oxygène toute la refléxion théologique et en faisant vive la foi et l'espérance dans le sens profonde de la vie, soit devant le cosmos, soit devant Dieu.

Celso Pinto Carias

Doutor pela PUC-Rio Professor da ITF de Petrópolis Professor do Dept. ${ }^{\circ}$ de Teologia da PUC-Rio 